\title{
Land-use transport models for climate change mitigation and adaptation planning
}

\author{
Alistair Ford \\ Newcastle University \\ alistair.ford@newcastle.ac.uk \\ Phil Blythe \\ Newcastle University \\ phil.blythe@ncl.ac.uk
}

\author{
Richard Dawson \\ Newcastle University \\ richard.dawson@ncl.ac.uk \\ Stuart Barr \\ Newcastle University \\ stuart.barr@ncl.ac.uk
}

\begin{abstract}
The adoption of the Paris Agreement has committed the world to limiting anthropogenic climate change to $2^{\circ} \mathrm{C}$ above preindustrial levels, adapting to climate risks, and fostering climate resilience. Given the high proportion of global emissions released by cities and the concentration of people living in urban areas, this will require an unprecedented reduction in greenhouse gas emissions and transformation of the built environment on a yet unparalleled timescale. This poses substantial challenges for urban land-use and transport planning and for the use of land-use transport models (LUTM), which have historically been developed to test incremental changes rather than the rapid transformations implied by the Paris Agreement.

This paper sets out the need for a new generation of tools to support the planning of a transition toward a low-carbon and resilient future, arguing that land-use and transport modeling tools are crucial to support this process. Recent developments in urban integrated assessment that link models of land-use and transport with other environmental models of greenhouse gas emissions and climate hazards show promise as platforms to assess the potential of urban policies in achieving the goals set out in the Paris Agreement.

The paper concludes by defining challenges for the LUTM community if it is to achieve these goals. Crucial will be the adoption of new modeling approaches to better represent rapid social and technological change and to concurrently assess the resilience and sustainability implications of different land-use and transport policies. Simple models to explore multiple scenarios of change must be integrated with more sophisticated models for detailed design. Collaborative approaches will be necessary to allow multiple stakeholders to use these tools to explore urban futures and design radical urban transitions across multiple and interdependent urban sectors.
\end{abstract}

Keywords: Urban modeling, transport, climate change, transitions, radical change, integrated assessment, co-benefits.

\section{Article history:}

Received: April 14, 2017

Accepted: August 4, 2017

Available online: January 5, 2018

Copyright 2018 Alistair Ford, Richard Dawson, Phil Blythe \& Stuart Barr http://dx.doi.org/10.5198/jtlu.2018.1209

ISSN: 1938-7849 | Licensed under the Creative Commons Attribution - Noncommercial License 3.0

The Journal of Transport and Land Use is the official journal of the World Society for Transport and Land Use (WSTLUR) and is published and sponsored by the University of Minnesota Center for Transportation Studies. 


\section{$1 \quad$ Introduction}

The Paris Agreement of December 2015, came into force on the November 4, 2016 (UNFCC, 2015). The agreement is a global commitment to limit global warming to $2^{\circ} \mathrm{C}$ above preindustrial levels and to "pursue efforts" to limit warming to $1.5^{\circ} \mathrm{C}$ (ibid). Governments agreed to reduce carbon dioxide $\left(\mathrm{CO}_{2}\right)$ and other Greenhouse Gas (GHG) emissions and improve their ability to adapt to the impacts of climate change, but the practical consequences of the deal, in terms of detailed future policy and practice, are yet to be fully-understood.

Despite agreeing to such ambitious targets, nations have made limited progress on emissions reductions since the first UN Climate Change Conference in 1995 (Olivier, Janssens-Maenhout, Muntean, \& Peters, 2016). Rogelj et al. (2016) states that "substantial enhancement or over-delivery on current [national GHG reduction commitments] is required to maintain a reasonable chance of meeting the target of keeping warming well below 2 degrees Celsius." Anderson (2015) showed that more than $20 \%$ of the remaining carbon budget for the $2^{\circ} \mathrm{C}$ target has already been emitted between 2010 and 2015. To limit total $\mathrm{CO}_{2}$ emissions to give a reasonable chance of avoiding a $2^{\circ} \mathrm{C}$ temperature rise $(650 \mathrm{Gt}$ ), emissions reductions must increase by $10 \%$ per year by 2025 , continuing at this rate toward the virtual elimination of $\mathrm{CO}_{2}$ from the energy system in developed nations by 2035 (ibid). By comparison, the EU's submission to the Paris Agreement, thought by many to be ambitious, is on course for a $40 \%$ reduction in total emissions by 2030 .

To establish successful future policies addressing the climate change, policymakers and civil society must acknowledge the agreements and what they mean in practical terms. Rockström et al. (2017) presented a roadmap of rapid decarbonization that demonstrates just how drastic the scale and pace of change must be, with emissions halving every decade across all sectors of the economy even with the use of "negative emission" technologies to remove GHGs from the atmosphere. Compared to the required reductions calculated by Anderson (2015) and Rockström et al. (2017), the current national government commitments tabled at the Paris COP would lead to warming of around $3^{\circ} \mathrm{C}$ (Tyndall Centre, 2016), far above the level at which scientists agree climate change would become devastating and unpredictable.

Alongside the conference of national governments which led to the Paris Agreement, 1000 of the world's city leaders met to agree action at city-level to reduce emissions and improve resilience (UCLG, 2015). This included a commitment to exceed the expected goals of the international agreement, and to concurrently pursue policies for adaptation and resilience. Cities and city regions, where the majority of $\mathrm{CO}_{2}$ is released, offer a foci for mitigation efforts. Cities are also, however, a foci of vulnerabilities, and must prepare to adapt to an uncertain future of $2^{\circ} \mathrm{C}$ global temperature increases. Cities will be pivotal in climate change mitigation and adaptation challenges, exemplifying possibilities and learning from each other globally (ICLEI, 2016). Efforts to reduce GHG emissions can additionally lead to cobenefits such as reduced air pollution, increased greenspace, higher resilience, and a better quality of life (Stern, 2007).

The need to adapt to climate change whilst mitigating against it presents a number of problems to policymakers. Beyond $3^{\circ} \mathrm{C}$ of global warming, adaptation becomes uncertain, and limits to adaptation must be determined through cost assessments (UNFCC, 2011). While the knowledge of gross effects is important for global policy making, cities require much more detailed information on the consequences and tensions of policy decisions within their jurisdiction to assist with policy-making (Dawson, 2011). Land-use and transport policies are an important part of the portfolio of possible measures (Walsh et al., 2011; Revi et al., 2014). Further, there are many trade-offs between adaptation and mitigation (Dawson, 2011): measures to mitigate against the threats of warmer world leading to negative impacts 
in terms of GHG emissions, economic performance, or social outcomes. Conversely, policies to reduce emissions, such as densification of urban areas (Larson, Liu, \& Yezer, 2012; Creutzig, 2014; Levinson \& Krizek, 2015) could lead to increased vulnerability to expected increases in climate extremes. City planners must therefore think systematically and examine possible interactions and sequential effects.

Given the urgent need for urban areas to lead both mitigation and adaptation efforts, the requirement to understand radically-different possible urban futures, and examine the implications of these in terms of $\mathrm{CO}_{2}$ emissions and resilience to climate change is increasingly vital. Integrated land-use transport models (LUTM), giving the possibility to understand future socio-economic and development trajectories in urban areas, form a core tool for understanding the implications of policy decisions. These models allow the exploration of the spatial context of urban futures, providing the potential to examine interlinkages with environmental, economic, and social sustainability. They provide an opportunity to assist policymakers with developing plans that are consistent with both adaptation and mitigation efforts.

Two such examples of integrated land-use, transport, and environmental models are the Ruhrgebiet model developed in Germany, and the Tyndall Centre Urban Integrated Assessment Framework (UIAF) in the UK. The Ruhrgebiet model examines the effect of integrated land-use transport policies on $\mathrm{CO}_{2}$ emissions at a national, regional, or local scale, alongside implications on economic and social sustainability (Schwarze et al., 2017). The Tyndall Centre UIAF considers mitigation and adaptation together in a systemic way, with consistent scenarios underpinning calculations of emissions from energy and transport, and risks and adaptation to climate hazards (Walsh et al., 2011).

This paper will now examine the potential of integrated land-use transport models in assisting decision-makers with the huge challenge of meeting the mitigation targets in the Paris Agreement whilst ensuring the resilience and sustainability of their urban areas. The Tyndall Centre UIAF and Ruhrgebiet models will be used as examples, the assessment of co-benefits and trade-offs between mitigation and adaptation explored, and further potential for the use of such models discussed. The paper will finally conclude by setting out the challenges which must be addressed by the LUTM community to assist with this rapid transition in urban areas, the potential for linking with other models, and the need to use models in novel ways.

\section{$2 \quad$ Urban mitigation strategies}

Mitigation policies against climate change rely on a reduction in GHG emissions to slow the rate of global temperature increases. Given the need for extremely rapid GHG emissions reductions, a portfolio of measures across all sectors of urban function must be explored (Rockström et al., 2017). Many cities have mitigation strategies, setting out their policies to achieve these reductions by a given time (Heidrich et al., 2016). For example, London's target is a 60\% reduction in $\mathrm{CO}_{2}$ emissions by 2025 (GLA, 2011). Transport emissions currently contribute $22 \%$ of London's total (GLA, 2015). The mitigation strategy aims for a $48 \%$ reduction in transport emissions by 2025 , with a new strategy to achieve zero-carbon transport by 2050 (GLA, 2017), through a package of demand reduction, modal-shift, and technological innovations. Emissions consistent with achieving the $1.5^{\circ} \mathrm{C}$ target, however, require substantial cuts and a large deviation from the business as usual (BaU) trajectory (GLA, 2011; Creutzig et al., 2016). Analysis of 200 European cities (Reckien et al., 2014) showed that current mitigation commitments would only reduce emissions by $27 \%$ within the EU.

The IPCC 5th Assessment Report (AR5) (Sims et al., 2014) describes the options available to cities for emissions reductions from transport, including both demand reduction and technological developments. Policies include densifying urban landscapes to avoid journeys, restructuring logistics systems (for example, one ton of goods transported by trains produces $76 \%$ fewer $\mathrm{CO}_{2}$ emissions than the same 
weight by lorry (Allan et al., 2016)), investing in non-car modes, improving vehicle efficiencies, and introducing new fuels. Transport emissions include those from vehicles and control systems, passenger travel, and freight transportation. The report also emphasizes that urban form is important, minimizing trips where possible through judicious land-use policies. Rockström et al. (2017) show that by the 2030s "adequate" carbon taxes must be in place on transportation, the internal combustion engine must be rare for land transportation, and "sustainable urbanization" must be the norm.

Many cities cite technological developments, such as electrification of transport, in strategies for emissions reductions from transport (Heidrich et al., 2016). Technology will not, however, be a silver bullet. There are ambitious national targets for the uptake of electric vehicles, with the UK Committee for Climate Change aiming for $60 \%$ of all vehicle sales to be ultra-low emission vehicles (ULEV) by 2030 (UKCCC, 2013)) and 100\% by 2040, giving a 100\% ULEV road fleet by 2050 . The average age of cars in the EU is around ten years, however, and current projections for uptake of EVs suggested the most optimistic share of non-petrol or -diesel vehicles will be $9 \%$ by 2020 (ibid). Uptake of EVs will also be limited by charging infrastructure (Neaimeh et al., 2015), material availability for batteries (Heidrich, Ford, Alderson, Dawson, \& Manning, 2015; Spiers, 2015), and supply of electricity from low-carbon sources. With current rates of EV take-up across Europe, and current grid decarbonization rates, technology will not alone produce the required rates of emissions reductions to achieve complete decarbonization by 2035 (Brand, Cluzel, \& Anable, 2017).

Since the required cuts to $\mathrm{CO}_{2}$ emissions are unlikely to be achieved by relying on technological solutions, policies of demand reduction and behavior change must be pursued in parallel (Creutzig et al., 2016). The IPCC AR5 report highlights the need to focus on strategies of "avoid" and "shift" (i.e., reducing or eliminating the need for journeys, or shifting those necessary journeys to less carbon-intensive modes) rather than simply "improving" efficiency of current patterns of behavior, demand, and use (Sims et al., 2014). The Stockholm Environment Institute (Whitelegg, Haq, Cambridge, \& Vallack, 2010) set out a vision for zero carbon transport in the UK, showing that transport-as-usual would lead to a $217 \%$ increase in $\mathrm{CO}_{2}$ emissions, but a combination of spatial planning, technological, fiscal, and behavioral change measures could achieve a 100\% reduction in transport emissions by 2050 .

The reality on the ground in most countries, however, is that aspirations expressed in the Paris Agreement do not match-up with levels of action. In the UK, for example, investment is still focused mainly in road schemes, airport expansion, and logistics centers not connected to rail systems. There has been little modal shift away from private car travel over the last 20 years. The integration of land-use and transport policy and planning is key to achieving these strategies, developing urban forms that make low-carbon transport an obvious option to citizens and businesses.

Such drastic and systemic change is a complex process, and involves institutional change alongside behavioral and technological change (Beddoe et al., 2009). Models, however, are often used to simplify complexities and gain an insight into the possible implications of change. Models therefore provide leverage points in the system and can allow change to be accelerated by demonstrating feasible and possible options, allowing experimentation with different policies, persuading stakeholders, and providing an endogenous perspective (Ghaffarzadegan, Lyneis, \& Richardson, 2011). Complex and sophisticated integrated LUTMs are well-established, with the capabilities to model numerous aspects of the urban system (Hunt, Kriger, \& Miller, 2005; Acheampong \& Silva, 2015). Such models are vital for planning, assessment, and communication of urban strategies to achieve required mitigation levels. The ReVisions model from Cambridge University, for example, tested the impact of urban form on achieving GHG savings (Hargreaves, Cheng, Deshmukh, Leach, \& Steemers, 2017) and translated that urban form to small-scale simulations of neighborhood and building scale development (Hargreaves, 2015). By providing the tools to examine the concomitant effects of land-use and transport policies and associated 
socio-economic and infrastructure changes on GHG emissions, such models can advance the understanding of a complex problem and explore potential solutions.

The way that models themselves are used must also be changed; rather than attempting to forecast, with limited success, what might happen on current trends (Levinson, 2016), models could be used instead for backcasting (Robinson, 1990). Backcasting allows planners to define a future state that must be met and work backwards to identify policies to connect that state to the present. Knowledge of carbon budgets and required emissions reductions sets the limit which must be met, and possible strategies that achieve required reductions can be identified through modelling. Such techniques could encourage politicians and citizens that change at such unprecedented pace and scale is feasible, even if difficult. Integrated LUTMs could, rather than testing options to aid mobility, or improve economic growth, be used to determine the packages of land-use policies, urban forms, and fiscal measures to enable a fast and equitable transformation from the current urban system to one consistent with the Paris Accord.

It is clear, therefore, that integrated simulation of land-use and transport futures to test potential packages of policy options, linked to economic and environmental assessment, is a vital tool for determining the optimum mitigation strategy. Demand must be reduced, and models can be used to show how that could be achieved, with avoid and shift strategies instead of efficiency improvements. Radical and bold ideas may be needed, but concepts such as "disappearing traffic" (Cairns, Atkins, \& Goodwing, 2002) show that radical transport policies, linked with suitable land-use planning policies, may not - contrary to urban planning lore-cause disruption. Buchanan (1958) suggested in "Mixed Blessing" that if cars were to be removed entirely from our cities then there wouldn't be a disaster, but there would be inconvenience. The Mercator project (see below and Schwarze et al., 2017) tested the effect of a $€ 24$ fuel price in their model, showing that it leads to the almost complete abandonment of the private car. Jin (2016) accidentally removed private car travel from his analysis and the resulting land-use pattern was a return to small "medieval"-type settlements with very local activities and services.

LUTMs could also allow policymakers to test such radical options, identify unintended consequences and test regulation to avoid them, and to ensure for example that energy efficiency does not simply lead to increased energy use instead of savings. Portfolios of measures will be needed, with a number of policies put in place together to achieve change, and the city-scale analysis of such policies in integrated land-use transport models is a vital tool to understand the implications and to examine conflicts and trade-offs within those portfolios, and with the adaptation policies which must be developed in parallel.

\section{Urban adaptation strategies}

Whilst it is crucial for urban areas to tackle mitigation challenges, cities must concurrently prepare for the changes in climate that have already been set in motion and consider adaptation. Even global warming limited to a $1.5^{\circ} \mathrm{C}$ increase will see significant change in climate patterns and extremes (IPCC, 2017), yet mitigation strategies are typically more advanced than adaptation plans (Heidrich, Dawson, Walsh, \& Reckien, 2013). Addressing the issue of urban resilience to a changing climate, in particular increases in frequency and severity of extreme weather events, adds additional complexity to the challenges faced by urban decision-makers. The EU Covenant of Mayors (Covenant of Mayors, 2015) has been signed by 687 European cities to commit to reducing $\mathrm{CO}_{2}$ emissions by $40 \%$ by 2030 while simultaneously enhancing their resilience, adopting an integrated approach to mitigation and adaptation.

The IPCC Fifth Assessment (AR5) identified the complex nature of climate vulnerability in urban areas (Revi et al., 2014). In particular, it highlights the interactions between climate change and socioeconomic change, and the interdependencies in cities which may lead to increased vulnerability. The impacts of climate change will include increasing mean and extreme temperatures, more frequent and 
intense rainfall events, and a reduction in water availability (ibid). The IPCC also make clear that climate change will impact a large cross-section of urban functions, infrastructure, and services, with such impacts occurring both at the location where the climate threat is experienced and, via interdependent networks of resource supply, in other more remote locations (Seto, Güneralp, \& Hutyra, 2012).

Hunt and Watkiss (2011) reviewed potential future climate change impacts on cities and highlighted that large metropolises such as London are heavily-reliant on transport networks to support daily commuter flows and the movement of goods. Any climate impacts on the supporting transport infrastructure on which cities rely could lead to knock-on effects on urban populations. Gasper et al. (2011) show that extreme weather events will disrupt interconnected urban systems and lead to impacts across multiple economic sectors. These impacts will be both direct (damage to infrastructure or buildings, or loss of life) and indirect (disruption to urban function and losses to the economy as the result of the damage). Through these interconnected networks, disruption to one spatial location in the city can lead to further disruption elsewhere (Hallegatte, Henriet, \& Corfee-Morlot, 2011). Similarly, the labor supply in a city, in the form of commuters, can be disrupted by damage to infrastructure networks. The effective and reliable operation of transport systems is therefore key to ensuring cities are resilient to future climate change.

The risk to urban areas from future climate change is a function of hazard, vulnerability, and exposure. Hazard can be defined as a potentially damaging physical event (UNISDR, 2009) and future changes are driven by climate change. Vulnerability, "the characteristics of a group in terms of their capacity to resist" (IFRC, 1999), and exposure, "the degree to which a system is exposed to significant climatic variations" (IPCC, 2001) are governed by socio-economic, land-use, or infrastructure changes. Land-use and transport planning is key in reducing risk, with population change and demands for land determining the extent to which people are exposed to future climate hazards (Lavell, 2003). Risks include those to human health, such as those caused by extreme temperatures, which could me managed through changes to land-use and transport policy (Harlan \& Ruddell, 2011).

Potential future climate changes at city scale can be assessed through techniques such as stochastic downscaling based on observed past events and future emissions pathways (e.g. the UKCP09 climate scenarios (Kilsby et al., 2007; Jones, Kilsby, Harpham, Glenis, \& Burton, 2010)). Urban-scale models of climate hazards are becoming increasingly viable, with the use of Cloud computing (Glenis, McGough, Kutija, Kilsby, \& Woodman, 2013) and simplified parameterization (de Ridder, Lauwaet, \& Maiheu, 2015) allowing physically-based simulation of extreme weather events at sufficient resolution for urban risk assessment. Integrating the outputs of such simulations with modelled changes in vulnerability and exposure projected by land-use transport models can allow mapping of locations where risks are highest under different climate scenarios (Jenkins et al., 2014).

Since long-term changes in vulnerability and exposure within urban systems are driven by government policy and population or economic growth at national and regional scale, these drivers must be considered to assess the ability of cities to adapt to the effects of climate change (Bulkeley \& Betsill, 2005; Adger, Hughes, Folke, Carpenter, \& Rockström, 2005a). For example, the WHO guidance on Heat Health Action Plans (Bickler, Mattheis, Hales, Marin, \& WHO, 2008) explicitly states "long-term urban planning" as a potential response to future increases in heat-wave incidence. Thus, integrated LUTMs are key to understanding scenarios of future socio-economic aspects of change, and linking them to environmental factors allows the testing of potential policies to reduce the risk from changes in climate.

The integration of land-use and transport with environmental models also allows the analysis of trade-offs between mitigation and adaptation to be better understood by urban planners and decisionmakers. As outlined above, some mitigation policies (such as densification of urban areas) may lead to 
reduced GHG emissions but can also have negative effects on urban resilience. The same is true in the inverse, with some adaptation policies leading to increased GHG emissions despite improving urban resilience (Dawson, 2011). For example, retrofitting existing buildings with air-conditioning can reduce the risk from increased future temperate extremes but will also lead to increased energy demand, anthropogenic heat emissions, and, if not carefully managed, higher GHG emissions.

The feasibility of adaptation options must also be assessed through cost assessments (Adger, Arnell, $\&$ Tompkins, 2005b), allowing the comparison of various adaptation options within the framework of integrated models of land-use and transport. Adaptation can be targeted at different points in an urban system and effectiveness of such options is highly-dependent on the structure, urban form, and stresses of a particular area. For example, green adaptation can be used to reduce surface run-off, grey adaptation can be used to protect infrastructure in the place where impacts are felt, or soft adaptation can be used to change the use of the system and reduce criticality (Willows, Reynard, Meadowcraft, \& Connell, 2003). Each of these types of intervention requires knowledge of future patterns of land-use, urbanization, infrastructure load, and travel patterns, making the use of integrated LUTMs a valuable tool in their assessment.

\section{Current state of the art in integrated land-use transport modeling for climate change assessment}

While integrated models of land-use, transport, and climate change issues are rare, some attempts have been made to achieve such integration. Two existing urban integrated assessment models will be briefly described here; the Ruhrgebiet model that is part of the Mercator project, and the UK Tyndall Centre's urban integrated assessment work in London. Both of these examples linked LUTMs with other environmental models of greenhouse gas emissions and climate hazards. This review will consider the challenges faced when integrating such models but also the potential of the approach for helping to understand the future policy options to address climate change adaptation and mitigation.

The Ruhrgebiet model (Schwarze et al., 2017) was developed as part of a four-year program funded by the Mercator Foundation to understand how the Ruhr area of Germany, one of the major urban agglomerations in Europe, may look after a transition from fossil fuels to renewable energy. Urban structure, land-use, socio-economic characteristics, transport of people and goods, and the environment were considered in an integrated modeling framework, allowing the identification of interactions, tensions, and synergies between them. The project examined the most suitable conditions for an energy transition to a lower-GHG future to occur, through a combination of technology and behavior.

The model considered two approaches to addressing the issue of the energy transition: conditional forecasts, to determine which impacts and outcomes could be expected for a given combination of energy demand reduction and efficiency measures, and backcasting, to determine which combination of energy demand reduction and efficiency measures would need to be implemented to achieve a given target. By employing scenarios of the economy (in terms of taxes, investments, or charges), land-use (densification, mixed-use development, or building regulations), transport (pricing, infrastructure improvements, speed limits, car-sharing), or building design (energy retrofitting, renewable generation), these questions can be answered for various portfolios of future policy to the year 2050. For each scenario the model simulates spatial patterns of activity (residence, employment, buildings), mobility (trips, travel time, travel mode), and the resultant environmental impacts (e.g. energy consumption, GHG emissions, air and noise pollution, land take, or biodiversity loss).

The methodology employed in the Ruhrgebiet model utilizes that IRPUD model (see Figure 1) developed by the Institute of Spatial Planning at the University of Dortmund (Wegener, 2011). The model simulates urban land-use, mobility, and environmental effects using a nested hierarchy of three 
spatial scales, from the European scale SASI model (Wegener, 2008) to the local scale. IRPUD simulates markets of labor, land, housing, and non-residential buildings to create future projections of firm locations, housing development, construction activity, internal migration, commuting and other travel flows, land-use change, and resultant energy use and environmental impacts. Policy measures, such as land-use regulation, economic subsidies, social housing provision, infrastructure development, and transport costs can be simulated to influence the decisions of private actors in the system, and thus environmental outcomes.

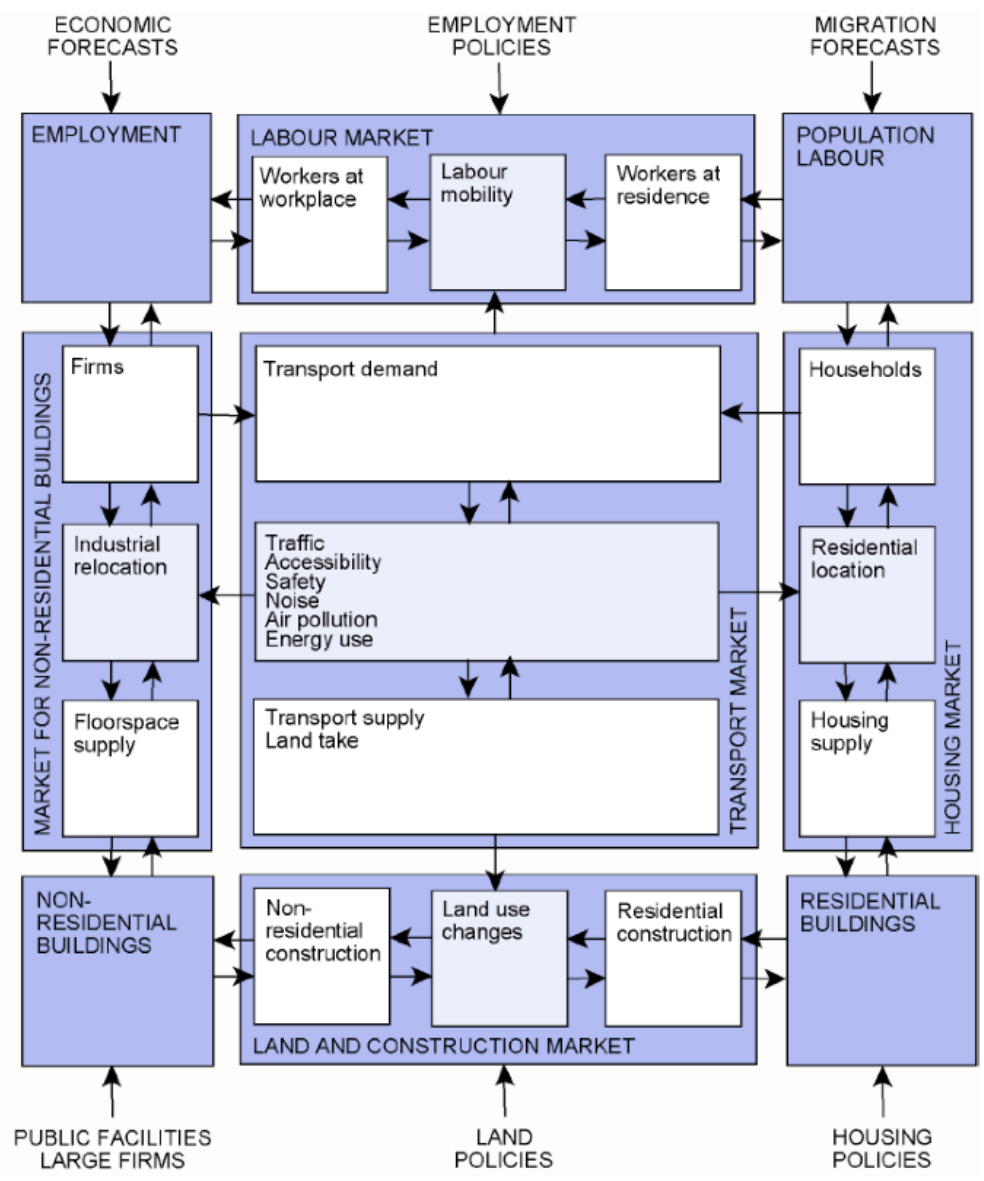

Figure 1: Conceptual description of the IRPUD model showing linkages between population, employment, land-use, and transport via a series of markets

Through use of scenarios, estimations of future energy use from households, firms, and transport can be obtained across the urban system. Combinations of policy measures, such as increasing energy costs or subsidies for investment in renewables, can be examined in terms of their impact on decisions of households or firms, urban form, or GHG emissions from transport. Through the sophisticated modeling system, more extreme scenarios can be tested in an attempt to backcast the packages of policy measures needed to meet the targets in the Paris Agreement (e.g., experimentations with extremely high fuel prices).

The second example of integrating LUTM and climate change is the Urban Integrated Assessment Framework (UIAF) developed by the Tyndall Centre in the UK and applied to greater London area (Hall et al., 2009; Walsh et al., 2011). The UIAF was developed to allow the long-term simulation of the major processes of climate impacts and the major processes of economic, population and land-use 
change to be performed at city scale. The UIAF models multiple scales of spatial process and activity within cities and their intersection with future climate change hazards such as flooding, heat and drought, allowing their integrated assessment at city scale (see Figure 2).

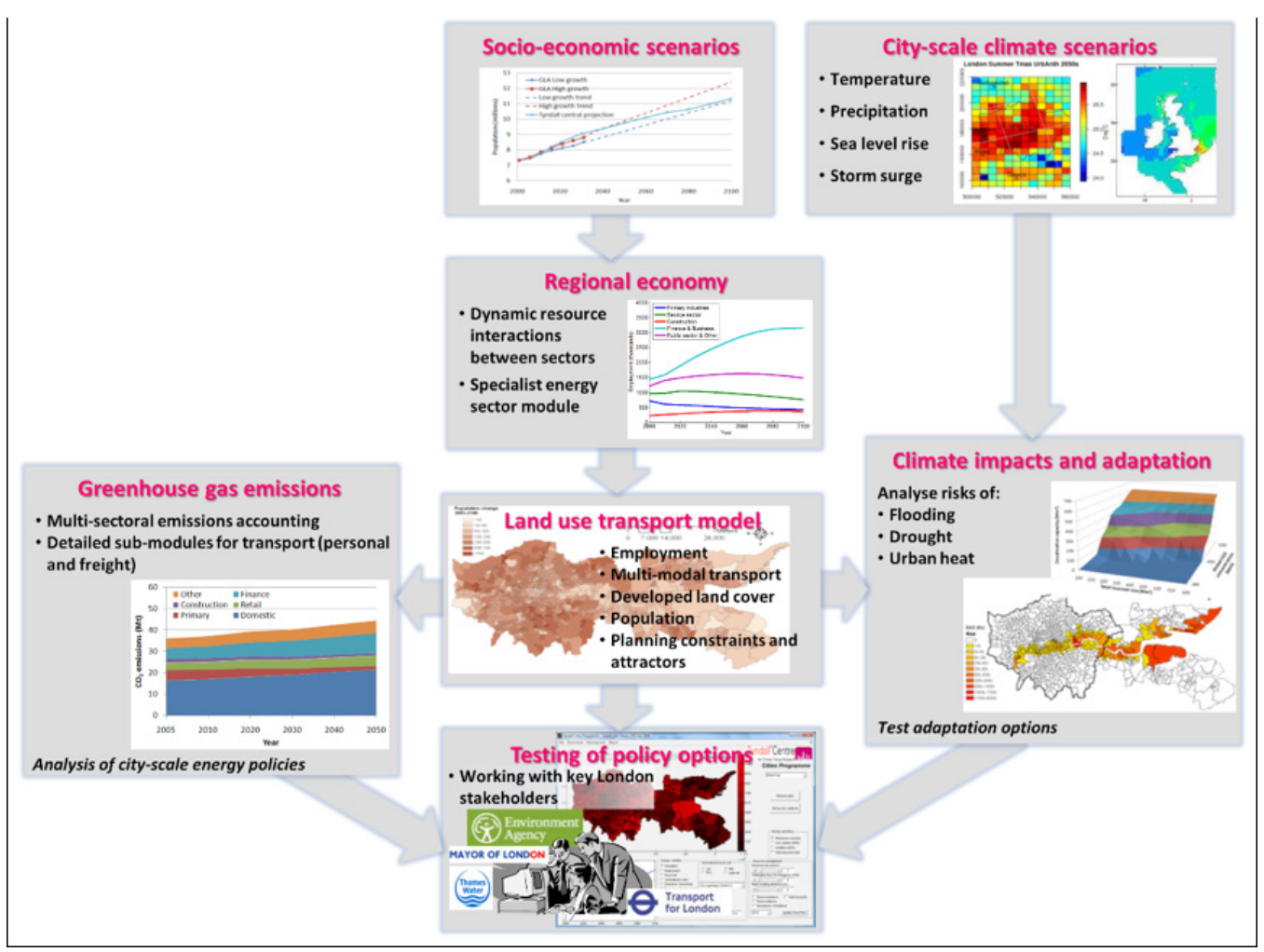

Figure 2: Conceptual model of the Tyndall Centre UIAF, showing linkages between regional and local scenarios of land-use, population, transport, and climate

Two exogenous inputs are used to drive scenarios of socio-economic and climate change; long-term employment projections up to 2080 from a combined econometric and input-out model (Junankar, Lofsnaes, \& Summerton, 2007) driven by the global E3MG model (Barker, Foxon, \& Scrieciu, 2008), and future spatial climate hazards derived using projections to the year 2100 from regional climate models (RCMs), linked through a "spatial weather generator" to produce correlated $5 \mathrm{~km}$ daily time-series of rainfall, temperature, humidity, wind and sunshine (Kilsby et al., 2007; Jenkins et al., 2014). These can be used to provide spatial hazards such as heatwaves, flooding from pluvial, fluvial and tidal sources and drought.

A simple population model was developed to allow future scenarios of transport and land-use planning, driven by the exogenous city-scale economic and population inputs, to be tested. This is a Lowry-style gravity model (Lowry, 1964) based on accessibility and employment locations. Accessibility is modelled using a GIS-based generalized cost tool, simulating different modes across the city and allowing rapid testing of new infrastructure investment scenarios (Ford et al., 2015). Population patterns can be mapped to land development changes using a simple cellular automata growth model, taking weighted inputs representing planning constraints and policy drivers. This model translates population projections from the zonal model to a grid of future urban development, allowing an understanding of the potential exposure of population to spatial climate hazards, and thus testing of resilience under different planning scenarios. 
By integrating consistent simulations of population and land-use change with impact and emission modeling the UIAF allows the testing of mitigation and adaptation policy options concurrently. This allows the exploration of synergies, trade-offs, or conflicts between adaptation and mitigation. For example, a planning policy of restricting new development in the floodplain, thus reducing the risk, may require increasing population density in new developments (increasing risk from heatwaves), moving that development elsewhere in the city (potentially increasing GHG emissions from commuting travel), or relaxing planning restrictions in other places (losing green land and risking biodiversity). These kinds of policy tensions can be exposed even by simple models of transport and land-use change.

The UIAF has also been employed to simulate indirect impacts on transport by flooding caused by extreme rainfall, assessing the risk by combining spatial simulations of hazard, exposure, and vulnerability on the transport network (Pregnolato et al., 2016). Dynamic simulations of floodwater depths across the urban domain for a given land-use and climate (e.g., rainfall intensity and duration) scenario are linked to measures of exposure (scenarios of transport infrastructure and vehicle trips) and vulnerability (a function relating flood depth to driving speed (Pregnolato, Ford, Wilkinson, \& Dawson, 2017)). The disruption caused by such effects can be characterized using Value of Time to convert time delays into monetary terms and estimate the costs to the users of the transport network, and thus the city as a whole. Such calculations allow an estimates of the total cost of disruption which can be compared to the costs of adaptations which could be used to reduce these effects.

The system-scale analysis of such events in an integrated modeling framework allows the comparison of different adaptation options to be tested. Grey adaptation, in the form of traditional engineering approaches, can protect the road links themselves, whilst green adaptation can be targeted upstream from the locations of disruption by tracing water flowpaths away from critical points. Soft adaptation, in the form of behavioral or management changes (e.g., better information during flood events, changes to land-use, employment locations, or travel mode choice) could reduce exposure to the flood hazard. Such interventions may need to be flexible, so that solutions can be adapted as climate change impacts grow in the future and exposure and vulnerability varies through socio-economic changes, analysis of which is made possible through integrated modelling.

\section{$5 \quad$ Challenges for the land-use transport modeling community}

The examples considered in the previous section are initial forays into the use of integrated land-use transport modeling for planning of mitigation and adaptation in urban areas. Whilst some advances have been made, the challenges faced by the modeling community can be clearly seen. The range of sophisticated integrated LUTMs now developed by the community make it possible to assess the packages of policy measures required to address this increasingly urgent problem. The scale of change required makes planning and assessment of options difficult, but the land-use transport modeling community can assist in those decisions if models are employed for new applications, in new ways, and linked to other models from the economics and environmental modeling communities.

\subsection{Challenge 1: Adopt and integrate new approaches to socio-economic simulation of land use and transport systems}

The need to examine rapid transitions from our current land-use and transport policies toward more sustainable futures requires integration of models across numerous fields. Some attempts have been made to using economic approaches such as transition theory, a method to describe the process of change from one state to another (Rotmans, Kemp, \& Asselt, 2001). Köhler et al. (2009) demonstrated a combination of agent-based modelling, systems dynamics, and transition theory to examine pathways 
toward sustainable mobility. Such approaches, linked with models like the Ruhrgebiet project, could lead to a wider understanding of the geographical and social constraints on the required transitions toward urban travel consistent with the Paris Agreement, to examine the factors that could most influence rapid transition (for example, which urban forms would aid those transitions to happen more quickly?). The use of backcasting, as applied in the Ruhrgebiet model, is also a means to limit the number of possible future options available to explore only those which align with the Paris Agreement.

\subsection{Challenge 2: Integrate external factors that could support a rapid shift toward mitigation and adaptation}

Metcalfe and Dolan (2012) and Garcia-Sierra, van den Bergh, and Miralles-Guasch (2015) have reviewed the potential of behavioral economics in transport decision-making. Issues such as artificiallylow fuel prices and information gaps affect the behavior of individuals and prevent them from choosing lower-carbon options when it comes to transport. McCollum et al. (2017) demonstrated approaches for improved representation of human behavior in models of transportation choice. Further linkages of behavioral aspects of traveler choices, and the geographical and societal factors that influence them, could be integrated into LUTMs, and would give a greater insight into the potential for rapid transitions toward low-carbon travel.

Such behavioral nudges could be strengthened by the inclusion of further externalities and cobenefits in models of land-use and transport choices. Wider costs to society, instead of individuals, could give an insight into the benefits of making choices that are not necessarily cost-minimizing. For example, Santos, Behrendt, Maconi, Shirvani, \& Teytelboym (2010) discussed the inclusion of externalities in models of road transportation to encourage more rapid progress toward low-carbon travel options. Cui and Levinson (2016) showed how measures of transport accessibility can be extended to include further external costs, thus capturing the true impact of travel decisions on factors like GHG emissions or air pollution. This can be extended toward further engagement with the public, such as in the "Full Cost of My Commute" tool used in Vancouver (Wilson et al., 2015) showing how externalities in transport can be communicated effectively to show the benefits to individuals and society, not just in terms of $\mathrm{CO}_{2}$ emissions, by changing travel behavior. Some of these changes could benefit both adaptation and mitigation (e.g., modal shift toward cycling would both reduce emissions from transport but also improve resilience, as cycle travel is less easily disrupted by flooding) but additional modeling approaches are required to capture these active modes (Panter, Heinen, Mackett, \& Ogilvie, 2016). Such co-benefits may make the transition more rapid: the air quality emissions issue regarding NO2 and diesel may have an unintended consequence of nudging individuals and businesses toward ULEV vehicles.

\subsection{Challenge 3: Use models in new and collaborative ways}

The ability of tools to communicate the urgency and multiple benefits of urban mitigation and adaptation policies are vital to ensure community buy-in to any proposed policies. Land-use and transport models are often expensive and difficult to use, and are often used to "justify" unsustainable schemes that achieve the opposite of what is required for sustainable travel. Simple models, such as those employed by the Tyndall Centre, can be used in a collaborative and conversational sense, to talk through options, to test scenarios, or to demonstrate knock-on effects and complexities with local people and community leaders. Using models in a group setting, with decision-makers and stakeholders around a table, could lead to a greater understanding of the system.

Examples such as the work of Hickman, Ashiru, \& Banister (2010) with VIBAT in London, show how collaborative solutions can be put together in an interactive environment based on complex model- 
ing results. Such participatory modeling can reduce the chance of community rejection of model results, with co-creation and participatory planning offering a better opportunity to bring people along with the process. They may in turn embolden politicians to support more radical policies, with better knowledge of the potential impacts, instead of what is most popular at the current time. Ostrom (2010) pointed to the need for polycentric decision-making at multiple scales to avoid the "Tragedy of the Commons" of climate change, including local stakeholder involvement, and the need for enabling tools and models. Thus, the use of integrated land-use and transport models should move away from the predict and control paradigm toward adaptive governance, enabling experimentation and learning from experience.

\subsection{Challenge 4: Further embrace dynamic, microscopic, and simple models}

The move toward microsimulation and dynamic modeling in LUTMs also provides opportunities for understanding climate change mitigation and adaptation challenges. Since short-term disruption during extreme climate events, such as flooding, is a dynamic and fast-moving problem, it could be possible to link dynamic simulations of both flood water and driver response. Dynamic simulations, rather than equilibrium transport models, would allow responses to be modelled more reliably, with microsimulation giving the ability to understand the responses of agents to the disruption caused to transport systems. Microsimulation may also help with understanding the impacts of rapid technological developments on travel behavior, particularly on individuals' tour-based travel decisions. New technologies that enable transportation to be used as a system rather than a series of under-connected modes is emerging under the badge of Mobility as a Service (MaaS) (Blythe, 2016a). This, coupled with automation, electromobility and changes in demographics, suggests that transport is on the cusp of some real transformations that will help deliver the de-carbonization agenda (Blythe, 2016b) and LUTMs must be developed to explore this potential.

An alternative approach to the use of complex, often "black box" models, was taken by the Tyndall Centre to adopt the simpler, more interactive approach as proposed by Batty (2013). Such models, with transparent parameterization and use of simple scenarios, enable greater understanding by users, policymakers, and the public. Moreover, it enables the application of such models around the world, particularly in the developing nations where future urbanization will be most rapid, not just in data-rich cities (e.g., Walsh et al., 2013). Lovelace (2016) suggests keeping the terminology of models but making them more accessible through online tools, exposing the equations and hypotheses inside the models, making more use of scenarios with simple, open, and flexible software. There are also opportunities to exploit new data sources, such as data collected through citizen science or open data, to assist in understanding and modeling the transition toward sustainable development (IEAG, 2014).

\subsection{Challenge 5: Embrace and communicate uncertainty openly}

A final problem is the huge uncertainty in projections of future climate, socio-economic, and land-use changes (especially over the long timescales required for urban planning and infrastructure investment). One approach to addressing this uncertainty using scenarios, testing mitigation and adaptation policies against a set of future "what if" cases (Rogers, 2015). Another approach, developed by Caparros-Midwood, Barr, and Dawson $(2015,2017)$, used a genetic algorithm to identify pareto-optimal solutions to urban planning problems. This framework used simple models to test a set of competing objectives for an urban system: reduction in emissions from transport, and minimizing risk to climate hazards, whilst developing enough land to meet population projections. This framework allows the generation of thousands of development permutations, testing each against the competing objectives. Thus a paretooptimal set of solutions which offer the highest scores against the multiple criteria can be identified, 
with each member of the set forming a unique land-use scenario. Such a tool could help planners to assess the options they face and under uncertain socio-economic and climate futures, and determine the most sustainable option. Formal assessment of the uncertainty of modeling results will also be required, especially given the additional uncertainty in the range of potential input variables (such as fuel prices), which could be highly influential on model outputs.

\section{Summary}

The necessary transitions for urban areas if they are to meet the targets set out in the Paris Agreement and ensure urban areas are resilient and sustainable are unprecedented. Efforts in the LUTM community are, however, already producing a new generation of tools to help understand how such transitions might be possible and which policy measures may best achieve them. The VIBAT tool allows policymakers to test portfolios of measures to reduce emissions. The Ruhrgebiet model integrates GHG emissions from transport and buildings to be examined and policies tested in an integrated system, including feedbacks. The ReVisions model considered sustainable visions for urban form to determine the carbon savings and translate that urban form to small-scale simulations of neighborhood and building scale development. The Tyndall Centre UIAF looked at mitigation and adaptation in an integrated assessment. Further efforts at developing such integrated models will allow a greater understanding of the interactions and feedbacks between land-use, transportation, the environment, and policy

Progress in conceptual development of models and computing power, alongside changes to the way models are used, are essential if community is to be in a strong position to support the efforts to meet the ambitious targets of the Paris Agreement. Emerging integrated modeling approaches, coupled with collaborative approaches to devise alternative urban futures, provide great promise. Such models can be used to test, understand, and help urban dwellers envision the radical options that would not only meet the goals of the Paris Agreement, but also ensure resilience and sustainable urban living.

\section{Acknowledgements}

The authors are grateful for discussions and advice from Prof Dr.-Ing. Michael Wegener that has improved this paper. The authors are grateful for funding from the UK's Engineering and Physical Sciences Research Council (EPSRC) through the LC Transform (EP/N010612/1) project, and the ARCADIA: Adaptation and Resilience in Cities: Analysis and Decision making using Integrated Assessment (EP/ G061254/1) project; the European Commission project RAMSES: Reconciling Adaptation, Mitigation and Sustainable Development for Cities (Project ID: 308497). 


\section{References}

Acheampong, R. A., \& Silva, E. (2015) Land use-transport interaction modeling: A review of the literature and future research directions. Journal of Transport and Land Use, 8(3), 11-38. doi: http:// dx.doi.org/10.5198/jtlu.2015.806

Adger, W. N., Hughes, T. P., Folke, C., Carpenter, S. R., \& Rockström, J. (2005a). Social-ecological resilience to coastal disasters. Science, 309(5737), 1036-1039.

Adger, W. N., Arnell, N. W., \& Tompkins, E. L. (2005b). Successful adaptation to climate change across scales. Global Environmental Change, 15(2), 77-86.

Allan, C., Whittaker, M., Rawcliffe, A., Dyer, R., Woodcock, A., \& Bowden, D. (2016). Future potential for modal shift in the UK rail freight market, Department for Transport. Retrieved from http:// www.arup.com/ /media/Publications/Files/Publications/F/Future_Potential_for_Modal_Shift_in_ the_UK_Rail_Freight_Market.ashx

Anderson, K. (2015). Duality in climate science. Nature Geoscience, 8(12), 898-900. doi: 10.1038/ ngeo 2559

Barker, T., Foxon, T., \& Scrieciu, S. S. (2008). Achieving the G8 50\% target: Modeling induced and accelerated technological change using the macro-econometric model E3MG. Climate Policy, 8, S30-S45.

Batty, M. (2013). Visually-driven urban simulation: Exploring fast and slow change in residential location. Environment and Planning A, 45, 532-552.

Beddoe, R., Costanza, R., Farley, J., Garza, E., Kent, J., Kubiszewski, I., \& Martinez, L. (2009). Overcoming system roadblocks to sustainability: The evolutionary redesign of worldviews, institutions, and technologies. Proceedings of the National Academy of Sciences, 106(08), 2483-2489

Bickler, G., Matthies, F., Hales, S., Marin, N. C., \& World Health Organization. (2008). Heat-health action plans: Guidance. Retrieved from http://www.euro.who.int/_data/assets/pdf_file/0006/95919/ E91347.pdf

Blythe, P. T. (2016a, October). The potential for mobility as a service-A UK government perspective. Proceedings of the 23rd World Congress on Intelligent Transport Systems, Melbourne, Australia.

Blythe, P. T. (2016b, October). Understanding the potential for big data in making transport smarter in cities. Lecture to the Alan Turing Institute, London, UK.

Brand, C., Cluzel, C., \& Anable, J. (2017). Modeling the uptake of plug-in vehicles in a heterogeneous car market using a consumer segmentation approach. Transportation Research Part A: Policy and Practice, 97, 121-136. doi: http://doi.org/10.1016/j.tra.2017.01.017

Bulkeley, H., \& Betsill, M. (2005), Cities and climate change: Urban sustainability and global environmental governance. Oxon, UK: Routledge.

Buchanan, C. (1958). Mixed blessing: The motor car in Britain. London, UK: Leonard Hill.

Caparros-Midwood, D., Barr, S., \& Dawson, R. (2015). Optimized spatial planning to meet long-term urban sustainability objectives. Computers, Environment and Urban Systems, 54, 154-164.

Caparros-Midwood, D., Barr, S., \& Dawson, R. (2017). Spatial optimization of future urban development with regard to Climate risk and sustainability objectives. Risk Analysis. doi: 10.1111/risa.12777

Cairns, S., Atkins, S., \& Goodwin, P. (2002), Disappearing traffic? The story so far. Proceedings of the Institute of Civil Engineers - Municipal Engineer, 151(1), 13-22.

Covenant of Mayors for Climate and Energy. (2015). Covenant of Mayors text. Retrieved from https:// www.covenantofmayors.eu/IMG/pdf/covenantofmayors_text_en.pdf 
Creutzig, F. (2014). How fuel prices determine public transport infrastructure, modal shares

and urban form. Urban Climate 10(1), 63-76.

Creutzig, F., Fernandez, B., Haberl, H., Khosla, R., Mulugetta, Y., \& Seto, K. (2016). Beyond technology: Demand-side solutions for climate change mitigation. Annual Review of Environment and Resources, 41(1), 173-198.

Cui, M., \& Levinson, D. M. (2016). Full cost analysis of accessibility. Retrieved from http://hdl.handle. net/11299/181544.

Dawson, R. J. (2011). Potential pitfalls on the transition to more sustainable cities and how they might be avoided. Carbon Management, 2(2), 175-188. doi: 10.4155/cmt.11.8

de Ridder, K., Lauwaet, D., \& Maiheu, B. (2015). UrbClim—A fast urban boundary layer climate model. Urban Climate, 12, 21-48.

Ford, A., Barr, S., Dawson, R., \& James, P. (2015). Transport accessibility analysis using GIS: Assessing sustainable transport in London. ISPRS International Journal of Geo-Information, 4(1), pp. 124-149.

Garcia-Sierra, M., van den Bergh, J.C., \& Miralles-Guasch, C. (2015). Behavioral economics, travel behavior and environmental-transport policy. Transportation Research Part D: Transport and Environment, 41, 288-305. doi: http://doi.org/10.1016/j.trd.2015.09.023

Gasper, R., Blohm, A., \& Ruth, M. (2011). Social and economic impacts of climate change on the urban environment. Current Opinion in Environmental Sustainability, 3(3), 150-157.

GLA. (2011, October). Delivering London's energy future: The mayor's climate change mitigation and energy strategy. Retrieved from https://www.london.gov.uk/sites/default/files/gla_migrate_files_destination/Energy-future-oct11.pdf

GLA. (2015, June). The mayor's climate change mitigation and energy annual report: 2013-2014, Greater London Authority. Retrieved from https:/www.london.gov.uk/sites/default/files/gla_migrate_files_destination/CCMES\%20annual\%20report_2013-14_0.pdf

GLA. (2017, August). London environment strategy (Draft for public consultation). Retrieved from https:/www.london.gov.uk/sites/default/files/8314_gla_les_online_single_page.pdf

Glenis, V., McGough, A. S., Kutija, V., Kilsby, C., \& Woodman, S. (2013). Flood modeling for cities using Cloud computing. Journal of Cloud Computing: Advances, Systems and Applications, 2(1), 7.

Ghaffarzadegan, N., Lyneis, J., \& Richardson, G. P. (2011). How small system dynamics models can help the public policy process. System Dynamics Review, 27(1), 22-44. doi: 10.1002/sdr.442

Hall, J. W., Dawson, R. J., Walsh, C. L., Barker, T., Barr, S. L., Batty, M., Bristow, A. L., Burton, A., Carney, S., Dagoumas, A., Evans, S., Ford, A.C., Glenis, V., Goodess, C.G., Harpham, C., Harwatt, H., Kilsby, C. G., Kohler, J., Jones, P., Manning, L., McCarthy, M., Sanderson, M., Tight, M. R., Timms, P. M., \& Zanni, A. (2009). Engineering cities: How can cities grow whilst reducing emissions and vulnerability? Norwich, UK: The Tyndall Centre for Climate Change Research.

Hallegatte, S., Henriet, F., \& Corfee-Morlot, J. (2011). The economics of climate change impacts and policy benefits at city scale: A conceptual framework. Climatic Change, 104(1), 51-87.

Hargreaves, A. J. (2015). Representing the dwelling stock as 3D generic tiles estimated from average residential density. Computers, Environment and Urban Systems, 54, 280-300. doi: http://doi. org/10.1016/j.compenvurbsys.2015.08.001

Hargreaves, A., Cheng, V., Deshmukh, S., Leach, M., \& Steemers, K. (2017). Forecasting how residential urban form affects the regional carbon savings and costs of retrofitting and decentralized energy supply. Applied Energy, 186(3), 549-561. doi: http://doi.org/10.1016/j.apenergy.2016.02.095

Harlan, S. L., \& Ruddell, D. M. (2011). Climate change and health in cities: Impacts of heat and air pollution and potential co-benefits from mitigation and adaptation. Current Opinion in Environmental Sustainability, 3(3), 126-134. doi: http://doi.org/10.1016/j.cosust.2011.01.001 
Hazeldine, T., Kollamthodi, S., Brannigan, C., Morris, M., \& Deller, L. (2009). Market outlook to 2022 for battery electric vehicles and plug-in hybrid electric vehicles, Report for UK Committee on Climate Change. Retrieved from https://www.theccc.org.uk/archive/aws2/docs/CH6\%20-\%20AEA\%20 -\%20Market\%20outlook\%20to\%202022\%20for\%20battery\%20electric\%20vehicles\%20 and\%20plug-in\%20hybrid\%20electric\%20vehicles.pdf

Heidrich, O., Ford, A., Alderson, D., Dawson, R., \& Manning, D. (2015, July). UK climate change strategies in cities and the layers of cobalt supplies. Paper presented at the 8th biennial conference of the International Society for Industrial Ecology, Guildford, UK.

Heidrich, O., Reckien, D., Olazabal, M., Foley, A., Salvia, M., de Gregorio Hurtado, S., Orru, H., Flacke, J., Geneletti, D., Pietrapertosa, F., Hamann, J. P., Tiwary, A., Feliu, E., \& Dawson, R. J. (2016). National climate policies across Europe and their impacts on cities strategies. Journal of Environmental Management, 168, 36-45.

Heidrich, O., Dawson, R. J., Walsh, C., \& Reckien, D. (2013). Assessment of the climate preparedness of 30 urban areas in the UK. Climatic Change, 120(4), 771-784. (doi: 10.1007/s10584-013-08469).

Hickman, R., Ashiru, O., \& Banister, D. (2010). Transport and climate change: Simulating the options for carbon reduction in London. Transport Policy, 17(2), 110-125. doi: http://doi.org/10.1016/j. tranpol.2009.12.002

Hunt, A., \& Watkiss, P. (2011). Climate change impacts and adaptation in cities: A review of the literature. Climatic Change, 104(1), 13-49.

Hunt, J. D., Kriger, D. S., \& Miller, E. J. (2005). Current operational urban land-use-transport modeling frameworks: A review. Transport Reviews, 25, 3, 329-376

ICLEI. (2016). Climate change: Implications for cities. Retrieved from http://www.iclei.org/fileadmin/ PUBLICATIONS/Brochures/IPCC_AR5_Cities_Summary_FINAL_Web.pdf

IEA. (2016). International Energy Agency global EV outlook 2016. Retrieved from https://www.iea.org/ publications/freepublications/publication/Global_EV_Outlook_2016.pdf

IEAG. (2014). A world that counts: Mobilizing data for the sustainable revolution, report by Independent Expert Advisory Group to United Nations secretary general. Retrieved from http://www.undatarevolution.org/wp-content/uploads/2014/12/A-World-That-Counts2.pdf

IFRC. (1999). Vulnerability and Capacity Assessment: A Federation Guide. Geneva, Switzerland: International Red Cross and Red Cross Societies (IFRC).

Jenkins, K., Hall, J., Glenis, V., Kilsby, C., McCarthy, M., Goodess, C., Smith, D., Malleson, N., \& Birkin, M. (2014). Probabilistic spatial risk assessment of heat impacts and adaptations for London. Climatic Change, 124(1-2), 105-117.

Jin, Y. (2016, November). Personal communication at Symposium for the Integration of Land-Use and Transport Models, Raitenhaslach, Germany.

Jones, P. D., Kilsby, C. G., Harpham, C., Glenis, V., \& Burton, A. (2010). UK Climate Projections Science Report: Projections of Future Daily Climate for the UK from the Weather Generator. London, UK: UK Climate Impacts Program.

Junankar, S., Lofsnaes, O., \& Summerton, P. (2007, March). MDM-E3: A short technical description. Technical report, Cambridge Econometrics. Retrieved from http://www.camecon.com/

Kilsby, C. G., Jones, P. D., Burton, A., Ford, A. C., Fowler, H. J., Harpham, C., James, P., Smith, A., \& Wilby, R. L. (2007) A daily weather generator for use in climate change studies. Environmental Modeling and Software, 22(12), 1705-1719.

Köhler, J., Whitmarsh, L., Nykvist, B., Schilperoord, M., Bergman, N., \& Haxeltine, A. (2009). A transitions model for sustainable mobility. Ecological Economics, 68(12), 2985-2995. 
Larson, W., Liu, F., \& Yezer, A. (2012). Energy footprint of the city: Effects of urban land use and transportation policies. Journal of Urban Economics, 72(2-3),147-159.

Lavell, A. (2003). Local Level Risk Management: Concept and Practices. Quito, Ecuador: CEPRE-DENAC-UNDP.

Levinson, D. M., \& Krizek, K. J. (2015). The End of Traffic and the Future of Transport. Seattle: Amazon Kindle Editions.

Levinson, D. (2016). Forecasting urban travel: Past, present and future, by D. Boyce \& H. Williams. 2015. Cheltenham, U.K., \& Northampton, Massachusetts: Edward Elgar. Journal of Regional Science, 56: 548-550. doi: 10.1111/jors. 12273

Lovelace, R. (2016,September). Tools of the trade: Adapting 20th century transport models for 21st century challenges. Presentation given at Cycling and Society Symposium, Lancaster, UK. Retrieved from https://rpubs.com/RobinLovelace/213645

Lowry, I. S. (1964). Model of metropolis, memorandum RM-4035-RC. Santa Monica, CA: Rand Corporation.

McCollum, D. L., Wilson, C., Pettifor, H., Ramea, K., Krey, V., Riahi, K., Bertram, C., Lin, Z., Edelenbosch, O., \& Fujisawa, S. (2017). Improving the behavioral realism of global integrated assessment models: An application to consumers' vehicle choices. Transportation Research Part D: Transport and Environment, 55(Supplement C), 322-342. doi:https://doi.org/10.1016/j.trd.2016.04.003

Metcalfe, R., \& Dolan, P. (2012). Behavioral economics and its implications for transport. Journal of Transport Geography, 24, 503-511. doi: http://doi.org/10.1016/j.jtrangeo.2012.01.019

Neaimeh, M., Wardle, R., Jenkins, A., Hill, G. A., Lyons, P., Yi, J., Huebner, Y., Blythe, P.T., \& Taylor, P. (2015). A probabilistic approach to combining smart meter and electric vehicle charging data to investigate distribution network impacts. Applied Energy, 157, 688-698.

Olivier, J.G.J., Janssens-Maenhout, G., Muntean, M., \& Peters, J. A. H. W. (2016). Trends in global $\mathrm{CO}_{2}$ emissions; 2016 report. The Hague: PBL Netherlands Environmental Assessment Agency, European Commission, Joint Research Centre.

Oppenheimer, M., M. Campos, R. Warren, J. Birkmann, G. Luber, B. O’Neill, \& K. Takahashi, 2014: Emergent risks and key vulnerabilities. In C. B. Field, V. R. Barros, D. J. Dokken, K. J. Mach, M. D. Mastrandrea, T. E. Bilir, M. Chatterjee, K. L. Ebi, Y. O. Estrada, R. C. Genova, B. Girma, E. S. Kissel, A. N. Levy, S. MacCracken, P. R. Mastrandrea, \& L. L. White (Eds.), Climate change 2014: Impacts, adaptation, and vulnerability. Part A: Global and sectoral aspects. Contribution of Working Group II to the Fifth Assessment Report of the Intergovernmental Panel on Climate Change (pp. 10391099). Cambridge, UK, and New York, NY, USA: Cambridge University Press.

Ostrom, E. (2010). Polycentric systems for coping with collective action and global environmental change. Global Environmental Change, 20(4), 550-557. doi: http://doi.org/10.1016/j.gloenvcha.2010.07.004

Panter, J., Heinen, E., Mackett, R., \& Ogilvie, D. (2016). Impact of new transport infrastructure on walking, cycling, and physical activity. American Journal of Preventive Medicine, 50(2), e45-e53. doi: http://doi.org/10.1016/j.amepre.2015.09.021

Pregnolato, M., Ford, A., Robson, C., Glenis, V., Barr, S., \& Dawson, R. J. (2016). Assessing urban strategies for reducing the impacts of extreme weather on infrastructure networks. Royal Society Open Science, 3(5), 160023.

Pregnolato, M., Ford, A., Wilkinson, S, \& Dawson, R. (2017). The impact of flooding on road transport: A depth-disruption function. Transportation Research Part D: Transport and Environment 55(Supplement C): 67-81.

Reckien, D., Flacke, J., Dawson, R. J., Heidrich, O., Olazabal, M., Foley, A., Hamann, J. J-P., Orru, H., 
Salvia, M., de Gregorio Hurtado, S., Geneletti, D., \& Pietrapertosa, F. (2014). Climate change response in Europe: What's the reality? Analysis of adaptation and mitigation plans from 200 urban areas in 11 countries. Climatic Change Letters, 122(1-2), 331-340. doi: 10.1007/s10584-013-0989-8

Revi, A., Satterthwaite, D. E., Aragón-Durand, F., Corfee-Morlot, J., Kiunsi, R., Pelling, M., Roberts, D. C., \& Solecki, W. (2014). Urban areas. In C. B. Field, V. R. Barros, D. J. Dokken, K. J. Mach, M. D. Mastrandrea, T. E. Bilir, M. Chatterjee, K. L. Ebi, Y.O. Estrada, R. C. Genova, B. Girma, E. S. Kissel, A. N. Levy, S. MacCracken, R.R. Mastrandrea \& L.L. White (Eds), Climate Change 2014: Impacts, Adaptation, and Vulnerability. Part A: Global and Sectoral Aspects. Contribution of Working Group II to the Fifth Assessment Report of the Intergovernmental Panel on Climate Change. Cambridge, UK: Cambridge University Press.

Robinson, J. B. (1990). Futures under glass: A recipe for people who hate to predict. Futures, 22(8), 820-842.

Rockström, J., Gaffney, O., Rogelj, J., Meinshausen, M., Nakicenovic, N., \& Schellnhuber, H. J. (2017). A roadmap for rapid decarbonization. Science, 355(6331), 1269. doi: 10.1126/science.aah3443

Rogelj, J., den Elzen, M., Höhne, N., Fransen, T., Fekete, H., Winkler, H., Meinshausen, M. (2016). Paris Agreement climate proposals need a boost to keep warming well below $2^{\circ} \mathrm{C}$. Nature, 534(7609), 631-639. doi: 10.1038/nature18307

Rogers, C. D. F. (2015). The value of foresight and scenarios in engineering livable future cities. In Retrofitting Cities for Tomorrow's World. Chichester, West Sussex, UK: Wiley Blackwell.

Rotmans, J., Kemp, R., \& van Asselt, M. (2001). More evolution than revolution: Transition management in public policy. Foresight 3(1), 15-31.

Santos, G., Behrendt, H., Maconi, L., Shirvani, T., \& Teytelboym, A. (2010). Part I: Externalities and economic policies in road transport. Research in Transportation Economics, 28(1), 2-45. doi: http:// doi.org/10.1016/j.retrec.2009.11.002

Schwarze, B., Spiekermann, K., Wegener, M., Huber, F., Brosch, K., Reutter, O., Müller, M. (2017). Städte und Klimawandel: Ruhrgebiet 2050. Integriertes Modell Ruhrgebiet und Regionaler Modal Shift. Final report. Dortmund/Wuppertal, Germany: Spiekermann \& Wegener Urban and Regional Research, University of Wuppertal, Wuppertal Institute for Climate, Environment and Energy.

Seto, K.C., Güneralp, B., \& Hutyra, L. (2012). Global forecasts of urban expansion to 2030 and direct impacts on biodiversity and carbon pools. Proceedings of the National Academy of Sciences of the United States of America, 109(40), 16083-16088.

Sims R., Schaeffer, R., Creutzig, F., Cruz-Núńez, X., D’Agosto, M., Dimitriu, D., Figueroa Meza, M. J., Fulton, L., Kobayashi, S., Lah, O., McKinnon, A., Newman, P., Ouyang, M., Schauer, J. J., Sperling, D., and Tiwari, G. (2014). Transport. In O. Edenhofer, R. Pichs-Madruga, Y. Sokona, E. Farahani, S. Kadner, K. Seyboth, A. Adler, I. Baum, S. Brunner, P. Eickemeier, B. Kriemann, J. Savolainen, S. Schlömer, C. von Stechow, T. Zwickel \& J. C. Minx (Eds.), Climate change 2014: Mitigation of climate change. Contribution of Working Group III to the Fifth Assessment Report of the Intergovernmental Panel on Climate Change. Cambridge, UK, and New York, NY, USA: Cambridge University Press.

Spiers, J. (2015, February). Electric vehicles and critical metals, SETIS Magazine, European Commission. Retrieved from: https://setis.ec.europa.eu/setis-reports/setis-magazine/materials-energy/electric-vehicles-and-critical-metals-jamie-speirs

Stern, N. H., (2007). The economics of climate change: The Stern review. Cambridge, UK: Cambridge University Press.

Tyndall Centre. (2016). Global carbon budget 2016. Retrieved from http://www.tyndall.ac.uk/sites/default/files/Infographics2016.pdf 
UCLG. (2015, December). Paris City Hall Declaration. Retrieved from https:/www.uclg.org/sites/ default/files/climate_summit_final_declaration.pdf

UKCCC. (2013-December). Pathways to high penetration of electric vehicles. Report to UK Committee on Climate Change. Retrieved from https:/www.theccc.org.uk/wp-content/uploads/2013/12/ CCC-EV-pathways_FINAL-REPORT_17-12-13-Final.pdf

UNFCC. (2011). Assessing the costs and benefits of adaptation options: An overview of approaches. Retrieved from http://unfccc.int/resource/docs/publications/pub_nwp_costs_benefits_adaptation. pdf

UNFCC. (2015-February). Adoption of the Paris Agreement. Retrieved from https://unfccc.int/files/ meetings/paris_nov_2015/application/pdf/paris_agreement_english_.pdf

UNISDR. (2009-May). Terminology on disaster risk reduction. Retrieved from http://www.unisdr. org/files/7817_UNISDRTerminologyEnglish.pdf

Walsh, C. L., Dawson, R. J., Hall, J. W., Barr, S. L., Batty, M., Bristow, A., Carney, S., Dagoumas, A., Ford, A. C., Harpham, C., Tight, M., Watters, H., \& Zanni, A. (2011). Assessment of climate change mitigation and adaptation in cities. Urban Design and Planning, 164(2), 75-84.

Walsh, C. L., Roberts, D., Dawson, R. J., Hall, J. W., Nickson, A., \& Hounsome, R. (2013). Experiences of integrated assessment modeling in London and Durban. Environment and Urbanization, 25(2), 257-376. doi: 10.1177/0956247813501121

Wegener, M. (2008, August). SASI mode description, working paper. Retrieved from http://www. spiekermann-wegener.de/mod/pdf/AP_0801.pdf

Wegener, M. (2011). The IRPUD Model. Dortmund: Spiekermann \& Wegener Urban and Regional Research. Retrieved from http://www.spiekermann-wegener.de/mod/pdf/AP_1101_IRPUD_Model.pdf

Whitelegg, J., Haq, G., Cambridge, H., \& Vallack, H. (2010). Toward a zero carbon vision for UK transport. Stockholm, Sweden: Stockholm Environment Institute. Retrieved from https://www.seiinternational.org/mediamanager/documents/Publications/SEI-ProjectReport-Whitelegg-TowardsAZeroCarbonVisionForUKTransport-2010.pdf

Willows, R., Reynard, N., Meadowcroft, I., \& Connell, R. (2003). Climate Adaptation: Risk, Uncertainty and Decision-Making, Part 2 (pp 41-87). Oxford, UK: Climate Impacts Program, Oxford, UK. Retrieved from http://nora.nerc.ac.uk/2969/1/N002969CR.pdf

Wilson, G. S., Millar, C., McLaren, C., Millar, E., Rockafella, J., \& Poulos, G. (2015). What is the full cost of your commute? Moving forward. Discourse Media. Retrieved from http://movingforward. discoursemedia.org/costofcommute/ 